Winter 2014

\title{
Perceptions of Immigrant Criminality: Crime and Social Boundaries
}

Deenesh Sohoni

William \& Mary, dssoho@wm.edu

Tracy W. P. Sohoni

Follow this and additional works at: https://scholarworks.wm.edu/aspubs

Part of the Migration Studies Commons, Race and Ethnicity Commons, and the Social Control, Law, Crime, and Deviance Commons

\section{Recommended Citation}

Sohoni, Deenesh and Sohoni, Tracy W. P., Perceptions of Immigrant Criminality: Crime and Social Boundaries (2014). The Sociological Quarterly, 55(1), 49-71.

https://doi.org/10.1111/tsq.12039

This Article is brought to you for free and open access by the Arts and Sciences at W\&M ScholarWorks. It has been accepted for inclusion in Arts \& Sciences Articles by an authorized administrator of W\&M ScholarWorks. For more information, please contact scholarworks@wm.edu. 


\begin{tabular}{|l|l|}
\hline Journal Code: TSQ & Proofreader: Mony \\
\hline Article No: TSQ12039 & Delivery date: 06 Aug 2013 \\
\hline Page Extent: 23 & \\
\hline
\end{tabular}

\title{
PERCEPTIONS OF IMMIGRANT CRIMINALITY: Crime and Social Boundaries
}

\author{
Deenesh Sohoni* \\ The College of William and Mary \\ Tracy W. P. Sohoni \\ University of Maryland
}

Researchers studying the relationship between immigration and crime frequently note the discrepancy between actual rates and public perceptions of criminal behavior by immigrants. Analyzing staff and reader generated texts in a local newspaper, we find that this connection is maintained through a conflation of key terms, assumptions of the legal status of immigrants, and a focus on high-profile criminal acts. We argue that the discourse of immigrant criminality has been critical in constructing social boundaries used in recent immigration legislation. Our analysis helps explain why current scholarly findings on immigration and crime have had little influence in changing public opinion.

Our elected officials in Washington don't get it. Illegal immigrants have broken the law, and let's not forget the people who hired them. Those employers paid the immigrants below the minimum wage. That's against the law, and they should be heavily fined. I came to this country legally by applying and waiting for my background to be checked... What's wrong with these illegals not doing the same? (Last Word, Virginia Gazette, April 12, 2006)

Researchers studying the relationship between immigration and crime frequently note the discrepancy between actual rates and public perceptions of criminal behavior by immigrants (Hagan and Palloni 1999; Sampson 2008). A growing body of literature shows that immigrants are less likely to engage in crime than U.S.-born citizens (Butcher and Piehl 1998; Martinez and Lee 2000; Morenoff and Astor 2006; Desmond and Kubrin 2009), and that areas with growing immigrant populations have seen decreases in crime rates (Ousey and Kubrin 2009; Stowell et al. 2009; Wadsworth 2010).

Studies focused more specifically on Hispanic immigrants, lend further support for these findings. At the individual level, Miller (2012) finds that foreign-born Hispanic youth are less likely than their U.S.-born counterparts to engage in criminal activity, and that this is true across various Hispanic subgroups (Lopez and Miller 2011). Similarly, at the macro level, Lee, Martinez, and Rosenfeld (2001) find no positive relationship between the percentage of new immigrants in neighborhoods and Latino homicide rates in the border cities of Miami, El Paso, and San Diego (see also

\footnotetext{
${ }^{\star}$ Direct all correspondence to Deenesh S. Sohoni, Department of Sociology, College of William and Mary, PO Box 8795, Williamsburg, VA 23187; e-mail: dssoho@wm.edu
} 
Martinez 2002). In fact, Hagan and Palloni (1999) argue that the reason Hispanic immigrants, both documented and undocumented, tend to be over-represented in prisons has more to do with their encounters with the court system rather than their actual levels of crime.

Yet, despite evidence to the contrary, public opinion surveys suggest that a large number of Americans believe that continued immigration will lead to higher levels of crime (Kohut et al. 2006). ${ }^{1}$ This is particularly true when surveys emphasize the (il)legal status of immigrants. For instance, a 2006 Time Poll found that over 70\% of respondents were "very concerned" or "somewhat concerned" that "illegal immigrants" "increase the likelihood of terrorism in the U.S." and "increase the amount of crime," while a 2006 Fox News/Opinion Dynamics Poll found that 75 percent of respondents were "concerned" that "illegal immigration" could "lead to an increase in crime" (PollingReport.com 2010).

In this article, we examine public perceptions of immigrant criminality by analyzing coverage of immigration in the Virginia Gazette, a newspaper that serves greater Williamsburg, VA, ${ }^{2}$ an area that has recently witnessed a sizable increase in its immigrant population. In addition to articles, editorials, and regular columns by reporters and columnists, the Gazette prints readers' responses in the form of standard letters to the editor as well as anonymous contributions that editors compile in a section called the "Last Word." These candid expressions of opinions offer unique insight into how members of the general public substantiate their views regarding immigrants and crime.

To our knowledge, no other studies have examined public discourse on immigration and crime with this type of sample, and this article makes an important contribution to understanding how individuals construct immigrant categories and depict criminal behavior, thus shedding light on the discrepancy between consistent findings in the criminological literature that immigrants are not more likely than the native born to engage in criminal behavior and findings in opinion polls that show public concern that immigration leads to crime. This understanding has important policy implications in light of recent efforts to mobilize concern about immigration and increased crime to bolster support for restrictionist legislation.

\section{IMMIGRATION AND CRIME: SYMBOLIC BOUNDARIES AND THE RULE OF LAW}

Immigration scholars have long noted the importance of immigration for conceptions of national identity (Higham 1955; Haney López 1996). National narratives portray immigrants as an essential part of American history, encapsulated in the origin myth of the United States as a "nation of immigrants." This origin myth serves as a source of "national re-enchantment," whereby immigrants reinforce key American values such as hard work, upward mobility, and family values (Honig 2001:74-5). At the same time, nativist discourses also present certain immigrants as a threat to American society. This threat is both cultural, because of their (presumed) unwillingness or inability 
to assimilate, and social, because of their (presumed) displacement of American workers, and their (ab)use of social services and community resources (Perea 1997). Debates over immigration, therefore, are not just about the impact of immigrants on American society, but also about which immigrants are worthy or unworthy of national membership.

In a review of the use of "boundaries" in the social science literature, Lamont and Molnár (2002) describe several useful concepts for understanding how distinctions are made between immigrants and the impact this has on their social incorporation. Specifically, they distinguish between symbolic boundaries, which they define as the distinctions made by social actors to categorize and separate people into different groups, and social boundaries which are the "objectified forms of social differences manifested in unequal access to resources and social opportunity" (2002:168). Lamont and Molnár (2002:168-9) argue that only when there is shared consensus on symbolic boundaries can social boundaries be created. Our goal in this article is to examine the role of public discourse regarding contemporary immigration in helping create this shared consensus.

Media and social movement scholars emphasize the importance of how social issues are framed in whether and how they come to be seen as problematic (Gamson et al. 1992; Benford and Snow 2000; de Vreese 2012). Gamson and Modigliani (1989) define a frame as a "central organizing idea ... for making sense of relevant events, suggesting what is at issue" (p. 3). Benford and Snow (2000:613) stress that frames arise through contested struggles "over the production of mobilizing and countermobilizing ideas and meanings." In this article, we build on this literature by examining how "immigrant criminality" is being used as a frame to problematize immigration, as well as how its application serves to create social boundaries by defining which immigrants are considered problematic. More specifically, we examine how members of a local "public" draw on, interpret, and utilize the frame of "immigrant criminality" to understand local happenings-in this case the arrival of new immigrants to Williamsburg.

Historically, the dominant ideologies used to bolster restrictionist discourse have been the racial and cultural distinctiveness of "newer" immigrants (Zolberg 2000). However, in the past half-century, the use of racial and cultural distinctions has been increasingly discredited from both a biological and a political standpoint. In fact, the Immigration and Nationality Act of 1965, which removed the quota system based on national origins, marked the end of such distinctions in U.S. immigration policy.

At the same time, the current post-9/11 climate has created an opportunity for those seeking to restrict immigration to present their arguments in ways that do not necessarily depend on more overt forms of racial and cultural differentiation (Sohoni 2006). More and more, this has meant framing immigrants as a threat to law and social order. For instance, Brettell and Nibbs (2010) argue that local-level debates on immigration have increasingly come to rely on the "Rule of Law" to justify enacting ordinances against immigrants. Specifically, they argue that perceptions of immigrants, and in particular "illegal" immigrants, as lawbreakers provides an important symbolic and 
"exclusionary tool to further separate the target population as 'other', immoral, and out of control" (2010:17). Critically, Brettell and Nibbs (2010:17) suggest that the act of entering the United States without papers is then equated with and generalized to other forms of more serious criminal behavior.

This article can be seen as a portrayal of attempts to create a shared understanding of the relationship between immigration and crime occurring within one U.S. community. While this discourse reflects the events and situations particular to this community, it is reflective of similar discourses throughout the United States that have been used in recent attempts to move symbolic boundaries to social boundaries through legislation increasing the policing of immigrant communities. For instance, Arizona Governor Jan Brewer cited crime by "illegal immigrants" as a key factor in supporting Arizona State Senate Bill 1070, stating, "Border violence and crime because of illegal immigration are critically important issues to the people of our state... We cannot sacrifice our safety to the murderous greed of the drug cartels. We cannot stand idly by as drop houses, kidnappings and violence compromise our quality of life" (Brewer 2010). Furthermore, the Williamsburg area serves as a valuable illustration of how some "new immigrant destinations,"- small towns, rural, and suburban areas in the South and Midwest that have recently become destinations for immigrants from Latin America-are responding to the influx of newcomers (Mohl 2003; Jones 2008).

In the following section, we provide a brief history of Williamsburg, recent changes in its demographic composition, and general trends in local crime, before turning to our analyses of how these changes are being perceived and debated by members of the local community.

\section{GREATER WILLIAMSBURG-AN OVERVIEW}

Williamsburg provides an ideal site for this type of discourse analysis given that it mirrors many other parts of the country that have recently seen increased numbers of immigrants. Located on the Virginia Peninsula with an estimated population of 136,000 (US Census Bureau 2009), the greater Williamsburg area prides itself on maintaining a small town atmosphere despite nearby metropolitan areas such as Richmond, Norfolk-Virginia Beach, and Washington DC. At the same time, the area's prominent historical sites, which include Colonial Williamsburg, Jamestown, and Yorktown, along with several amusement parks, serve as a major tourist draw, bringing in hundreds of thousands of tourists each year (Colonial Williamsburg Foundation 2010).

Greater Williamsburg has also been characterized by relatively rapid population growth, much of it fueled by wealthy retirees attracted to the area for its "quality of life" and low taxes (Dawkins et al. 2007). ${ }^{3}$ Between 1990 and 2000, the overall population of greater Williamsburg grew by 32 percent and an additional 25 percent between 2000 and 2010 (Weldon Cooper Center for Public Service 2011). ${ }^{4}$ The resulting boom in housing construction, the continued needs of the tourist sector, and the growing requirements of retirement communities (e.g., elder care, landscaping), all have contributed to an increased demand for cheap labor. Like many areas of the "Nuevo 
South," this demand has been met in large part by immigrant labor, which in greater Williamsburg includes Hispanic immigrants, ${ }^{5}$ as well as European and Asian students here on J-1 visas. ${ }^{6}$

While there are no good data on the size or change of the foreign-born population in Williamsburg, one documented demographic change for the area has been the rapid increase in the size of the local Hispanic population. Between 1990 and 2007, the Hispanic population in greater Williamsburg nearly quadrupled in size, from approximately 1,250 to just over 4,700 , representing an increase from approximately 1.5 to 3.5 percent of the total population (Pew Hispanic Center 2009). Although the data do not indicate the percentage of this group that is foreign born, estimates for Virginia as a whole suggest that just under half of the Hispanic population is foreign born (Clapp 2011).

The increased size and visibility of the Hispanic population (both immigrant and native born) has led to intense debates regarding the consequence of these demographic changes for the local community. As with other new immigrant destinations, these debates have ranged from the economic impact of immigrants on the local job market and their fiscal costs with respect to the provision of social services, to the social challenges immigrants pose to "American society" because of their linguistic, cultural and racial differences (Massey 2008). In addition, recent local debates around immigrants have focused on their perceived criminality. This debate has occurred during a time in which Williamsburg has maintained crime rates considerably lower than the national average and has experienced a downward trend in crime that has mirrored the national trend (Federal Bureau of Investigation 2012).

\section{DATA AND METHODS}

This study is part of a larger research project focusing on how journalists and members of the public construct and use interpretative frames and social categories to make sense of the arrival of various immigrant newcomers within a local community (Sohoni and Bickham Mendez 2012). In order to examine public depictions of immigrant issues within the local sphere of the Williamsburg community, we conducted a content analysis of all texts that referenced immigrants or immigration appearing in the Virginia Gazette between January 2006 and December 2007, ultimately including 522 texts. ${ }^{7}$ This was a period during which immigration was a common topic in the national news because of legislative actions including the "Secure Fence Act of 2006" and the "Comprehensive Immigration Reform Act of 2007." Also during this period, several local crimes received extensive media coverage, which framed them as "immigration issues" by highlighting the undocumented status of the suspected perpetrators.

As previously noted, the Last Word section of the Virginia Gazette provides a unique view into how members of the public discuss and make sense of immigration. There are several advantages to this particular form of submission. The anonymity of these contributions, and the brevity of their length, means that their authors are likely to be more frank and open, as well as from a more diverse base than just those who 
would feel confident enough to write a letter to the editor. Conversely, the submission process, of composing an e-mail, writing a physical letter, or making a phone call, along with a delayed response of waiting for it to be published, is likely to weed out some of the "knee-jerk" responses that can arise in online forums. ${ }^{8}$ We believe this balance results in a contribution that is both more frank and from a wider base than typical published writings, while at the same time being more reflective of the thought process of individuals than most online forums.

Based on the existing literature on contemporary immigration discourse (Perea 1997; Chavez 2001, 2008; Sohoni 2006), we developed an initial coding guide to categorize the major themes found in our texts. Using a subsample of three months, we then conducted a pilot study to refine our coding mechanism, adding and collapsing categories to incorporate themes that emerged from the data set. Since many of the texts included multiple themes related to immigration, we assigned each text a primary code corresponding with an identified dominant theme and in some cases secondary codes for less prominent themes. ${ }^{9}$ Lengthy pieces that devoted attention to several themes were coded as multiple arguments. We ultimately defined six categories of texts: (1) culture, (2) economy and labor market, (3) government responsibility, (4) community resources, (5) crime/border enforcement, and (6) multiple arguments, of which the category "crime/border enforcement" became the primary basis for the current project.

In addition to assigning thematic codes to the texts, we also classified them by type (two types of Gazette generated texts: news articles, and op-ed/columns; and two types of reader generated texts: letters to the editor, Last Word entries), and by general, expressed attitudes regarding immigration: (1) "exclusionary"-that is, immigrants and/or immigration depicted in a negative manner; (2) "inclusive" - that is, sympathetic attitudes toward immigrants and support for more lenient enforcement; or (3) "balanced/mixed"- that is, news reporting and discussion of immigration issues in a purportedly "objective" manner, or which present both exclusionary and inclusive arguments. Each text was read and coded by at least two coders. ${ }^{10}$

The current study is based on the subsample of texts whose primary or secondary thematic category was crime/border enforcement. Texts in this category consisted of those that related immigration to the breaking of the law, including those that depicted immigrants as engaging in "illegal" activities, and those that posited the need for increased border control to stem the tide of "illegal" immigration. For the two-year period under review, we found 196 such texts. ${ }^{11}$ Thus, of the total number of references to immigration and immigrants in the Virginia Gazette for the years 2006 and 2007, over 37 percent make reference to the "criminality" of immigrants. Of these 196 texts, over 70 percent $(\mathrm{N}=145)$ were reader generated, either in the form of Last Word responses $(\mathrm{N}=122)$ or letters to the editor $(\mathrm{N}=23) .{ }^{12}$

Scholars have noted that much of the discourse on the criminality of immigrants relies on a conflation between the category of "illegal immigrant" and cultural images that present Mexicans (and other Latin American immigrants) as criminal "Other" (Chavez 2001; Santa Ana 2002; Dick 2011). Based on this literature and an initial examination of the texts, we subdivided our 196 texts into three categories. These 
categories were coded as: (1) immigrant illegality, in which the primary argument is the "illegality" of the undocumented status of some immigrants, (2) immigrant criminality, focusing on criminal acts other than "illegal" immigration, and (3) aiding and abetting the criminal activity of immigrants, in which businesses that use undocumented immigrant labor or organizations that assist undocumented immigrants are themselves critiqued for engaging in illegal behavior. ${ }^{13}$

Our analysis of these data consisted of two parts. First, we examined the frequency of each of these three arguments, as well as the ratios within each category for expressed attitudes. In addition, we also examined how the "criminality" of immigrants is linked to other critiques of immigrants. Second, we conducted a more detailed analysis of the arguments utilized to link, or contest the connection between, immigration and crime. In particular, we examined the rhetorical strategies used to frame the relationship between immigration and crime, and the language and imagery used to depict immigrant criminality.

The ultimate goal of this study is to shed light on the continuing discrepancy between empirical evidence on immigration and crime and public opinion by establishing how members of the public conceptualize immigrant categories and immigrant criminality, and how this may impact public policy concerning the policing of immigrants. Our research also contributes to the literature on framing and social boundaries by illustrating how audiences contest, reinterpret, and utilize frames to make sense of local conditions, as well as how this aids in creating symbolic boundaries.

\section{FINDINGS}

We begin our analysis by examining the arguments used in our three main categories: (1) immigrant illegality, (2) immigrant criminality, and (3) aiding and abetting the criminal activity of immigrants. In addition, we examine the relationship between these categories and the other thematic categories from the original data set. Of the five other thematic categories, only three were used frequently in combination with our crime categories. These three categories, (1) public services and resources, (2) government responsibility, and (3) economy and labor market, are covered in greater detail in the section on "Links to Other Restrictionist Discourse."

\section{Discourses on the Relationship between Immigration and Crime}

Immigrant Illegality

Of our three main categories, the dominant category was that of "Immigrant Illegality" $(\mathrm{N}=119)$, with the primary argument focused on the act of being in the country without proper documentation as a form of breaking the law. Within this category, over 75 percent of the depictions of immigrants were exclusionary (totaling 90) compared to 11 inclusive depictions and 18 balanced/mixed depictions (with the majority of balanced/mixed texts generated by the Virginia Gazette) (See Table 1). Typical of the exclusionary depictions were multiple Last Word commentators who articulated the view that "the act of illegal immigration is wrong" or that those who come here illegally 
JOBNAME: No Job Name PAGE: 8 SESS: 11 OUTPUT: Tue Sep 17 19:18:15 2013

/Xpp84/wiley_journal/TSQ/tsq_v55_i1/03tsq_12039

Perceptions of Immigrant Criminality

TABLE 1. Immigrant Criminality Categories and Expressed Attitude

\begin{tabular}{lllcc}
\hline Category & & Inclusive & Exclusionary & Balanced/Mixed \\
\hline Immigrant illegality & Total (119) & 11 & $90^{\mathrm{a}}$ & 18 \\
& Gazette generated & 2 & 4 & 11 \\
& Reader generated & 9 & 85 & 7 \\
Immigrant criminality & Total (69) & 3 & 37 & 29 \\
& Gazette generated & 0 & 1 & 29 \\
& Reader generated & 3 & 36 & 0 \\
Aiding/Abetting & Total (8) & 1 & 7 & 0 \\
& Gazette generated & 1 & 2 & 0 \\
& Reader generated & 0 & 5 & 0 \\
\hline
\end{tabular}

ancludes one political advertisement that was not classified as either Gazette generated or Reader generated.

"broke the law" by doing so (Last Word, Virginia Gazette, April 12 and 15, 2006). In fact, many readers argued that even if "illegals" are hardworking, their very act of cross$\square$ ing the border without documents makes them criminal (Last Word, Virginia Gazette, May 15, 2006).

This position, that undocumented border crossing is of a similar and equal nature as that of other criminal acts is best captured in a reader's comment stating "illegals are here illegally" ... they are "breaking the law as much as those who rape, steal, and murder (Last Word, Virginia Gazette, August 8, 2007)." In essence, this results in a conflation between "illegality" and other more serious criminal acts. Yet, while the argument that being "illegal" is equivalent to being criminal seems logical, upon reflection it is clear that the general public does not apply this standard to all illegal acts. As Brettell and Nibbs (2010) point out, people that drive above the speed limit, even intentionally, are not commonly referred to as "criminals" despite breaking the law.

This act of placing "illegal" immigrants in the same category as more serious criminals (i.e., rapists, murderers, and thieves) then allows the construction of social borders in which the undocumented (as well as those presumed to be undocumented) become undeserving of basic rights as well as deserving of targeted policing. In the above example in which the Last Worder argued that illegal immigration was "breaking the law as much as a person who steals, murders or rape," the person then goes on to say "Stop using my tax dollars to make illegals feel welcome" (Last Word, Virginia Gazette August 8, 2007). Or as another reader puts it, “... Illegal equals lawbreaker, which equals alien, non-entitled squatter-scavenger" (Dowling, Letters to the Editor, August 29, 2007).

The eighteen balanced/mixed texts in this section were primarily made up of reader generated comments that expressed a pro-legal immigrant but anti-illegal immigrant position, and Gazette generated articles discussing legislation or programs dealing with immigrants, or presenting both the positive and negative consequences of immigration, or describing the political platforms of local candidates for office. As one example 
of an article with pro-legal immigrant but anti-illegal immigrant sentiments a Gazette columnist quoted a local reverend who said "In this whole immigration issue, we are not saying we are against immigration. We are a nation of immigrants. Diversity is our strength, and it should be celebrated, not just tolerated. It's illegal immigration that poses a serious problem in view of $9 / 11$." This columnist further states "The majority of the mobs of illegals demanding their civil rights are not citizens. Therefore, they have no civil rights" (Johnson, Curmudgeon, May 10, 2006). Similarly, a Gazette reader attributes different characteristics to legal versus illegal immigrants:

There is a huge difference between legal and illegal immigrants. Legal immigrants looked forward to learning the language of our nation and joining in our culture. Today, our open borders allow people to come in illegally, breaking our laws. Many do not care about learning English. Some illegals have even been given free health care when some legal citizens cannot afford services (Shepherd, Letters to the Editor, January 11, 2006).

Also included in this category was Gazette coverage of local elections. Generally, these were reports of the often negative positions of candidates toward undocumented immigrants. For example, one summary of a local candidate noted he "says he would hold accountable employers who hire illegal aliens. Also wants facilities to detain illegals for processing" (Scorecard [of Politicians' Views], November 10, 2007). But, even these seemingly "objective" texts can contribute to the construction of social boundaries through their choice of language, a point discussed further in the following section.

The few rare cases that sought to moderate attacks on "illegal" immigrants based strictly on their undocumented status tended to highlight the work these individuals did, and their role in the US economy. Thus, one reader writes, "We need to accept that there are no simple solutions to illegals. They are honest, hard-working people who value family life. We need to move toward a path to the legalization of illegals" (Danko, Letters to the Editor, August 25, 2007). Another directly challenges a previous reader equating illegal immigrants with other criminals and also highlighting their role in the economy stating "Legal or not, these are not people sitting on their backsides waiting for the government to give them a handout. And to equate them with murderers, rapists and thieves is ignorant and xenophobic" (Last Word, Virginia Gazette, August 11, 2007). Yet, even while the few positive depictions focused on the hard work of immigrants, the far more common view of immigrant labor, particularly with respect to "illegal" immigrants, was that they kept wages low and increased unemployment for "Americans" (Last Word, Virginia Gazette, January 1, 2007; May 19 and 26, 2007).

Particularly striking across this category is the frequent conflation of the categories of "Hispanic," "immigrant," and "illegal," in which the terms are used interchangeably despite their distinct meanings. For instance, illustrating the conflation of "immigrant" with "illegal immigrant," a Last Word respondent wrote "I was furious to read the front page of my Gazette and see an article that is positive about illegal immigration. It's an 
outrage that the Gazette would do this" (Last Word, Virginia Gazette, May 13, 2006). The article to which the respondent referred was entitled "Immigrants flock to fill good jobs" (Kerr, La Vida Latina, May 5, 2006) and was specifically about legal immigrants, and included a sidebar entitled "Getting Here, Legally." Another Last Word respondent, in response to the same article, wrote "Nowhere in the article is the word "illegal" used. Anyone who illegally crosses our border is illegally in this country and, therefore, is an illegal immigrant" (Last Word, Virginia Gazette, May 13, 2006).

\section{Immigrant Criminality}

Our second largest category "Immigrant Criminality" consists of attempts to link immigration and immigrants to other forms of criminal activity $(\mathrm{N}=69)$. Unlike "immigrant illegality" the focus is not based on the (un)documented status of immigrants, but rather on linking immigrants to other forms of criminal activity. Commentators in the Gazette associate immigrants with a wide array of crimes; from Social Security and identity theft, to more serious criminal behavior such as drug involvement, gang membership, rape, and murder. Similar to the "Immigrant Illegality" category, exclusionary depictions greatly outnumbered inclusive depictions (37 to 3), with another 29 texts coded balanced/mixed, nearly all of which were Gazette reporting of policing activities or court cases where immigrants were involved.

Illustrating attempts to establish and validate the link between immigrants, and specifically "illegal" immigrants, to serious crime, one reader criticized an earlier Last Word entry that had contested that immigrants were not any more likely to engage in drug dealing; countering "To the Last Worder who said illegals don't sell drugs. According to the newspapers and police, these individuals bring, use and sell drugs here" (Last Word, Virginia Gazette, January 10, 2007).

Of critical importance in the "Immigrant Criminality" category is the relevance of local criminal events in depictions of the dangers of immigrants. These crimes contribute to the perception that any crime committed by immigrants is extraneous crime, or crime that would not have occurred were immigration restrictions stricter, or more strictly enforced. Two high-profile cases in the local area sparked this discourse. The first was the case of Oswaldo Martinez, a deaf and mute illegal immigrant from El Salvador who was charged with the rape and murder of a young girl in Williamsburg in $2005 ;{ }^{14}$ and the second was the case of Alfredo Ramos, an illegal

2 Mexican immigrant who killed two young girls in a DUI incident in nearby Virginia Beach in 2007. In particular, the Martinez case spurred extensive coverage in the Gazette with eight articles (mainly updates of competency hearings) and twelve Last Word responses.

Several respondents used these cases as support for the view that immigrants were purveyors of deadly actions. These local crimes frequently were framed by readers as primarily immigration issues:

He (Martinez) was crafty enough to get himself into this country illegally from El Salvador and crafty enough to stalk and kill an innocent teenager ... It is time to 
stop coddling illegals who come into this country and commit crimes. (Last Word, Virginia Gazette, October 18, 2006)

How much have we paid for Oswaldo Martinez who is accused of raping and murdering Brittany Binger? Look around and you find illegal aliens are committing more crimes, more rapes and more murders because they don't see us enforcing our laws. More Americans die each year at the hands of illegal immigrants than are dying in war. Our politicians stand back and do nothing ... It's time the politicians and judges be held ... responsible for allowing Americans to be terrorized in their own country. (Last Word, Virginia Gazette, August 22, 2007)

Now we have in the headlines yet another illegal immigrant who, while driving under the influence, slammed into the back of the vehicle carrying two teenage girls, killing them. (Last Word, Virginia Gazette, April 7, 2007)

Rather than viewing serious crimes committed by "illegal" immigrants as unique events that had little to do with their immigrant status, readers saw "illegal" immigration as the root cause of serious crime. For instance, one person wrote "... and when you feel like committing a crime, go ahead. With no proof of identification, police officers will tell you it is a waste of time to issue tickets or citations to suspected illegals. If you commit rape or murder, just claim you didn't know it was wrong" (Last Word, Virginia Gazette, February 22, 2006).

In extremely rare cases, readers noted that the criminal behavior of immigrants should not be viewed as necessarily because of their immigrant or legal status. For instance, one reader criticized the media portrayal of the drunk-driving fatality caused by Alfredo Ramos, saying "Bill O'Reilly is insensitive to the families of the victims of the drunk-driving accident. He blames illegal immigrants, but ignores the issue of drunk driving" (Last Word, Virginia Gazette, April 14, 2007).

The connection between immigrant status and criminal involvement is inadvertently reinforced by media coverage of criminal behavior by undocumented immigrants. ${ }^{15}$ While we code news coverage of criminal activities by immigrants in police blotters, court coverage, or other news articles as balanced/mixed and recognize that most coverage of immigrant crimes is presented objectively in tone; the labeling of the immigrants accused of criminal behavior by their (il)legal status, or even their immigrant status at all, creates a hyper-awareness of these individuals, and we argue a perception of their overrepresentation in criminal behavior. For example, the headline for a report on a local assault was "Illegal Immigrants Charged in Attack" (Kerr, May 2, 2007). In another case, the police blotter reported "Police responded to fight outside an apartment... Inside they discovered 8 illegal aliens" (December 23, 2006). Frequently, these instances of "neutral" reporting of local crimes specifying the immigration status of the offender were then followed by a flurry of responses by readers. If each case reported in the newspaper detailed when a crime was committed by a nativeborn citizen, we expect this would reduce the glare of the occasional case involving an undocumented immigrant. 
Furthermore, in cases in which the legal status of an immigrant is not defined, readers may "fill-in" the descriptor "illegal." Indeed, the previously cited example of readers objecting to an article that appeared positive toward illegal immigration, when in fact the article was about legal immigration, supports this claim. It appears that even the presence of a "Hispanic" name may be enough for a person to "fill-in" the descriptor of "illegal immigrant." For instance, this can be found in reference to an article on gang violence, where a Last Word respondent states "It is amazing that the Gazette printed an entire article about gangs in Virginia without mentioning illegal immigration. Even the FBI will say that Hispanics are the biggest growing gangs ..." (Last Word, Virginia Gazette, April 25, 2007) (emphasis added). Further support comes from a Last Word respondent who wrote, "In addition, illegal immigrants are frequently in trouble with the law. Just take a look at the Police Blotter. There's usually at least one Hispanic name on there" (Last Word, Virginia Gazette, August 11, 2007) (emphasis added). This is not surprising given past research where viewers of news programs were likely to remember a crime suspect being identified as black, even when no racial information was given or shown (Gilliam and Iyengar 2000). This process of "filling-in" information demonstrates one more way in which the conflation between "immigrant," "Hispanic," and "illegal immigrant" can take place.

\section{Aiding and Abetting}

Our final category, "Aiding and Abetting" turns the focus of criminal behavior from the immigrant to those that assist/benefit from these individuals. Thus, rather than focusing on the immigrant, in this category the discourse focuses on the businesses or social institutions that hire or aid immigrants. This category consisted of eight texts, seven of which were exclusionary depictions with one inclusive depiction.

Of particular concern, was that tolerance of "illegal" immigrants by private citizens, politicians, and law enforcement, would make the local area a sanctuary city. Echoing conservative pundits on Fox News, one reader warns of the danger of not actively pursuing "illegal" immigrants: "VA Beach has been labeled on Fox News as the 'Illegal Alien Sanctuary City' for Virginia for its don't ask, don't tell action. Will Williamsburg be next?" (Last Word, Virginia Gazette, April 11, 2007). Another reader responds that this is already the case, stating that a local apartment complex with a large number of Hispanics was not being policed despite its "illegal" occupants (Last Word, Virginia Gazette, April 18, 2007).

Interestingly, the sole inclusive depiction was that of a regular staff columnist who cautioned that a proposed bill by the Virginia House of Representatives would make individuals who helped illegal immigrants, even on humanitarian grounds, felons (Leadbeater, Notes from the Edge 1/24/07). ${ }^{16}$ Some readers, on the other hand, welcomed punishing those that aided "illegal" immigrants. For example, one reader suggested that citizens were responsible for reporting "illegals and employers looking for cheap labor" (Last Word, Virginia Gazette, April 1, 2006). This view that "illegal" immigration is being facilitated by businesses seeking cheap labor, and permitted by government officials at all levels, is further examined in the following section. 


\section{Links to Other Restrictionist Discourse}

One of the key findings in our data was the way readers utilized and linked immigrant criminality to other restrictionist discourses. Thus, immigrant criminality served as a "master frame" to critique all those who support immigration (Benford and Snow 2000). Throughout our data set, links were commonly made between immigration and crime and the three categories of (1) public services and resources, (2) government responsibility, and (3) economy and labor market. Surprisingly however, immigrant culture was rarely linked to crime. This runs counter to historical patterns, where the discourse regarding immigrants and crime included how the "culture" of immigrants, or the conflict between immigrant culture and American culture, resulted in crime (i.e., see Sutherland 1927, 1934). ${ }^{17}$

The most common discourse linked with immigrant criminality was that of (illegal) immigrants using public services and resources (62 texts). For instance, one reader complained that "illegal aliens"... "come into our communities unchallenged and deplete our resources through identity theft and unauthorized use of our health care and welfare systems" (Last Word, Virginia Gazette, February 10, 2007). Another complained that they are "tired of paying taxes to support illegal immigrants" ... who are "getting free medical care" (Last Word, Virginia Gazette, May 19, 2007). Typically, the use of these resources was depicted as "stealing" them from deserving tax-paying "Americans." For instance, one reader criticizes the use of educational resources by "illegal" immigrants, saying "... illegal immigrants receive in-state tuition at Virginia colleges and universities. Our taxes are being used to further the goals of lawbreakers while our children go without" (Last Word, Virginia Gazette, August 25, 2007).

Thus, immigrants are seen as criminal for stealing public resources which do not belong to them, making these services less available to native citizens, and also eroding the quality of these services. As one person writes, "why should a taxpayer be pushed aside to get services he or she is entitled to because an illegal immigrant walked in?... The quality of services is going down too" (Last Word, Virginia Gazette, August 11, 2007). Only rarely is the linkage made that immigrants, even "illegal" immigrants, deserve public resources on humanitarian grounds. One such reader responded to proposed legislation that would strip organizations of state and local funding if they were found to provide services to "illegal" immigrants, saying "I watched my (illegal immigrant) students' children smile, play, and laugh. The idea that Virginia would put these children's health more at risk makes me sick. We are better than that. We can address illegal immigration more humanely and more thoughtfully" (Koenig, Letters to the Editor, February 7, 2007).

Another common target for anti-immigrant discourse were the local, state, and national-level politicians who are accused of failing to enforce immigration laws and control the entry of immigrants into the United States (42 texts). This view is captured in an Essay on immigration by Beachum (September 29, 2007):

If illegal is defined as not legal or contrary to law, then would not elected and legally appointed sworn officials by their oaths be guilty of nonfeasance for 
allowing illegal immigrants to enter and remain in this county, state, and anywhere in the United States?

Blame was mainly directed to the national level; from President Bush, who was accused of ignoring issues that most Americans find important, such as "securing our borders and ports," and "enforcing immigration laws" (Byrd, Letters to the Editor, July 25, 2007); to Congress for trying to pass an "immigration bill making illegals legal without US citizens noticing” (Last Word, Virginia Gazette, May 26, 2007).

This attitude also manifested against local public officials who were unwilling to take a strong stance against "illegal" immigrants. For instance, when James City County considered following the lead of two other Virginia counties (Prince William County and Loudon County) that had passed local ordinances restricting social services to "illegal" immigrants, the county attorney reported that implementing this plan would not prove cost effective for the county. This led several Last Worders to question the county's response:

Prince William and Loudon are attempting to limit county services to illegals. Does anyone really believe that James City, Williamsburg and York, with their substantial growth, don't have a problem? (Last Word, Virginia Gazette, August 15, 2007a).

James City County attorney Leo Rodgers indicated it was not cost effective to deal with illegal aliens." ... Rodgers' job is to see that the law is enforced, not decide which laws should be enforced. (Last Word, Virginia Gazette, August 15, 2007b).

Several local politicians used this hostility toward immigrants in their election campaigns. For instance, in a campaign advertisement, Rob Wittman, in his (eventually successful) bid for a U.S. Congressional seat stated "Rob Wittman understands that illegal immigrants are breaking the law and burdening taxpayers. He will support tough measures to secure our borders" (Wittman, Campaign Advertisement, December 8, 2007). Similarly, we find a Gazette columnist, Cecil Johnson, praising Brenda Pogge, in her (also successful) bid for the Virginia House of Representatives, for her campaign brochure which depicted two brown-skinned men crossing a barbwire fence with the heading "Enough is Enough! It's Time to Get Tough on Illegal Immigration" (Johnson, September, 19, 2007).

The final common target for critique was businesses and employers that use immigrant labor (33 texts). A common attitude by readers was that "companies hire illegals for cheap labor" (Last Word, Virginia Gazette, May 26, 2007) and "illegals are only beneficial to employers" (Last Word, Virginia Gazette, June 2, 2007). A few go further and suggest that employers that hire "illegals," themselves should be treated as criminals (as previously described in our category of "Aiding and Abetting"):

Businessmen ... first entice illegal immigration and then illegally exploit the resulting illegal immigration, ... I believe that if you put these American criminals in jail where they belong, you won't have to spend billions on building a "Berlin Wall" 
around our country to slow immigration to a controllable level (Burke, Letters to the Editor, June 14, 2006).

As with most of these anti-corporate critiques, is the assumption that businesses are predominantly using illegal (rather than legal) immigrants.

\section{CONCLUSION}

Our data provide unique insight into the rhetoric used by the general public by expanding analysis beyond commonly available newspaper sources, such as editorials and newspaper articles, and examining discourse by citizens both in standard letters to the editor as well as the more unique Last Word entries. Specifically, entries to the Last Word are better able to capture the voice of average citizens by allowing readers to write short, anonymous opinion pieces. Although not a random cross-section of opinion, these readers' responses provide insight into how members of the general public maintain an image linking immigrants and crime, in spite of evidence to the contrary. Furthermore, this analysis offers a glimpse at how symbolic boundaries are discussed in public discourse, potentially affecting what social boundaries may be created.

While scholars of immigration and crime have provided a plethora of evidence that the crime rate of immigrants is not higher than that of U.S.-born citizens, our analysis demonstrates that the rhetoric used by members of the public relies on considerations beyond crime rates. For instance, the attention given to major criminal events (such as the rape and murder of a young girl, and the drunk-driving deaths of two girls caused by an immigrant) is framed as extraneous crime, or crime that would not have occurred had the person not been in the country. For these members of the public, while the crime rates of immigrants may be the same or lower than that of the native born, any crime committed by immigrants, regardless of their legal status, is seen as crime that would not have occurred had there been stricter restrictions on immigration, or greater enforcement of current laws. Even seemingly neutral depictions of crime stories, such as police blotters, can contribute to this perception when they mention the immigrant status of the suspect, as it draws attention to the immigrant issue. Such a distinction is not made when the suspect is native born and is thus rendered invisible to the public eye.

More critically, our analysis suggests that the public framing of "immigrant criminality' is based not solely on crimes that immigrants might commit while in the United States but also on their manner of entry there. The conflation of the undocumented status of some immigrants with other forms of criminality further maintains the link between immigrants and crime even in light of a lack of evidence of immigrants contributing to higher rates of other forms of crime. Thus, public opinion polls are likely to continue to find a link between immigration and crime as long as there is a perception of high numbers of immigrants entering the country illegally. These members of the public are less concerned with any additional crimes committed by immigrants, and rather consider the immigrant's undocumented status as criminal in itself. 
The link of undocumented immigrants as criminal by definition is exacerbated by a conflation in the public eye of immigrants, or specific groups of immigrants, as automatically being "illegal." That is, we repeatedly read accounts in which "immigrants" or "Hispanics" were used interchangeably with "illegal immigrants," demonstrating an assumption that any Hispanic or immigrant is undocumented. This link is further reinforced by media reporting, and is heavily dependent on innumeracy regarding migration patterns (i.e., overestimates of the size of the immigrant population and the percentage of the immigrant population that is in the United States illegally) (Sides and Citrin 2007; Citrin and Sides 2008).$^{18}$ As an example of this type of innumeracy and conflation on the national level, Lou Dobbs remarked in 2006 on his popular CNN show that "... it's costing us, no one knows precisely how much, to incarcerate what is about a third of our prison population who are illegal aliens." In reality, roughly 26 percent (closer to one quarter) of the federal prison population is comprised of noncitizens. This number does not distinguish between legal and illegal immigrants, and the federal prison population only holds approximately 12 percent of the total U.S. prison population. Thus, this number greatly exaggerates the number of immigrants in prison (which is closer to 6 percent of the prison population), and also confuses "immigrant" with "illegal immigrant" (Gonzalez and Goodman 2007).

This conflation of terms, and its role in the creation of social boundaries, can be seen playing out in locations beyond Williamsburg and is particularly problematic because it contributes to racial profiling. In July, 2007 in Prince William County, VA, a resolution was passed to increase detection and deportation of illegal immigrants. ${ }^{19}$ While concern about the link between "illegal" immigration and crime was cited as one of the main pushes behind the resolution, when later questioned by the United States Commission on Civil Rights, the Chairman of the Prince William Board of County Supervisors that had passed the resolution was unable to provide empirical evidence for this link. ${ }^{20}$ Not surprisingly, many of the characteristics used to detect "illegal" immigrants relied on broader ethnic characteristics. Similar resolutions have recently passed in Arizona (SB 1070) and in Alabama (HB 56), and now face legal challenges. ${ }^{21}$ Among the challenges to Arizona SB 1070 are concerns that it results in racial profiling. Among the many suits against the Arizona law are two suits filed by police officers arguing that such a law would hinder police investigation in areas that were predominately Hispanic, that to enforce the law would require violating the rights of Hispanics, and that it would leave officers open to being sued whether they enforced the law or not (Escobar v. Brewer et al., 2010; Salgado v. Brewer et al. 2010). Specifically, these complaints testify that there are no "race neutral criteria" by which to enforce the act (Escobar v. Brewer et al.: 2010:3-5), and that the Act will require the "use race as a primary factor in enforcing the various provisions of the Act" (Salgado v. Brewer et al. 2010:5).

A final finding of our analysis is that illegality and criminality of immigrants were not uncommonly used as "master frames" for a larger anticorporate and antigovernment critique (Benford and Snow 2000:618-9). That is, respondents would use immigration as a mechanism to criticize corporations for their use of immigrant labor, thus stealing jobs from "real Americans." This critique also extended to criticizing the 
government for failing to protect citizens from immigrants stealing jobs or public assistance by lax enforcement and laws regarding immigration. Thus immigration, and immigrant crime, served as only a single component of a larger critique against corporations and the U.S. government.

The results from the analysis indicate that empirical findings regarding immigration and crime have been unsuccessful in affecting public perceptions because the framework supporting this link depends on rhetoric that is not solely reliant on crime rates. In order to have an impact on public perceptions, academics need to address the discourse being used within the public arena to support this relationship. Our research highlights the interrelatedness of discourses related to crime and to immigration, such as what is included in the term "criminal," the assumptions of (il)legal status of immigrants or for members of certain ethnic or racial groups, and the importance of recognizing how people respond to specific crime stories. Thus, addressing public misconceptions relating immigrants to high crime rates depends upon also addressing these additional factors. This is particularly relevant given the current creation of social boundaries evidenced by restrictive immigrant legislation being put forth in many states and the recent Supreme Court ruling on AZ SB 1070, which critics contend leaves open the possibility of racial profiling (Cohen and Mears 2012).

Ultimately, the goal of this article was to understand why the image of the "criminal immigrant" remains so firmly entrenched in public discourse, and subsequently finds its way into public policy, even when sound empirical investigation has failed to provide a link between immigration and crime. While the origin of this image in the United States could arguably be related to the historical geographic settlement of immigrants in high crime areas, our research indicates that the discourse used to maintain this link goes beyond history and geography. We find a process in which an "outgroup" is defined and deemed threatening to the "in-group." Undocumented entry in the United States is conflated with other criminal acts, individual examples of immigrants committing crime are used to bolster this relationship, and economic and social service "threats" are framed in a "criminal" light. Conflation between use in terminology of "immigrant," "illegal immigrant," and "Hispanic" then blur the distinctions between the groups, and can heighten the perceived threat.

Our findings can be used to support perspectives that argue that in racially and ethnically stratified societies, growth in minority populations leads to fear among members of the dominant group that their privileges are being threatened, leading to greater prejudice toward members of minority groups (Blumer 1958; Blalock 1967). Ousey and Unnever further suggest that this can create a "racialized public sensitivity" where crime is conflated with out-groups and out-groups with crime (Ousey and Unnever 2012:590). But, whereas the group conflict theory takes group boundaries as a given, our research also points to how discussions around criminality, particularly through the conflation of Hispanic, immigrant, illegal, serves to help create the boundaries of the group that is considered threatening. We believe that until scholars are able to address the mechanisms by which the "out-group" is created and maintained, that belief in immigrant criminality will persist. 
JOBNAME: No Job Name PAGE: 18 SESS: 11 OUTPUT: Tue Sep 17 19:18:15 2013

/Xpp84/wiley_journal/TSQ/tsq_v55_i1/03tsq_12039

\section{ACKNOWLEDGMENTS}

Earlier versions of this article were presented at the annual meetings of the Society for the Study of Social Problems in Atlanta (2010) and the annual meetings of the American Society of Criminology in San Francisco (2010). We thank Graham Ousey and the anonymous reviewers at TSQ for their helpful comments on previous drafts of this article. We also are indebted to Jennifer Bickham Mendez for helping develop the data set used for this study.

\section{NOTES}

${ }^{1}$ In 2006, a third of respondents believed immigrants from Latin American countries "significantly increase crime." Yet, it is important to note that this reflected a decline from 1997 when 43 percent of respondents believed that Latin American immigrants increased crime.

${ }^{2}$ The greater Williamsburg area includes the city of Williamsburg, James City County, and Upper York County.

${ }^{3}$ Among the amenities that the greater Williamsburg area offers are world-class golf courses and multiple gated communities.

${ }^{4}$ The combined population for Williamsburg, James City County and York County was 88,813 in 1990, 117,353 in 2000, and 146,541 in 2010.

${ }^{5}$ Many Hispanic immigrants originally arrive on $\mathrm{H}-2 \mathrm{~B}$ visas, which allow companies to hire temporary labor for seasonal, nonagricultural employment in the United States.

${ }^{6}$ The J-1 Exchange-Visitor visa is designed for educational and cultural exchange, and allows recipients to work up to three months and to travel up to 30 days prior to the start of the program.

${ }^{7}$ The Virginia Gazette is published twice a week and has a paid subscription of 16,500 (Virginia Gazette 2012). Since not every section of the newspaper is published online, the two lead researchers for the broader project and their research assistants reviewed every printed issue of the Gazette to identify texts that contained keywords such as immigrant(s), immigration, foreigners, foreign workers, "illegals," "aliens," Mexicans, and Hispanics.

${ }^{8}$ Currently, e-mails make up over half of Last Word submissions. With the exception of personal attacks, libel, or comments deemed racist or bigoted, an estimated 80 percent of contributions to the Last Word are printed (Rusty Carver, Editor at the Virginia Gazette, e-mail communication, March 20, 2008).

${ }^{9}$ Several texts included more than one secondary code.

${ }^{10} \mathrm{Each}$ text was coded by one of the two lead researchers and by one of two research assistants for theme(s)/expressed attitude. In cases where coders differed in opinion, the lead researcher who had not served as original coder served as the arbitrator. A test of inter-coder reliability on a one month sample using the revised coding mechanism revealed a range of 0.81 to 0.88 .

${ }^{11}$ Of these 196 texts, 106 originally had Crime/Border Enforcement as their primary category, and 90 had it as a secondary category.

${ }^{12}$ Our data set included one political ad which was not counted as reader or Virginia Gazette generated.

${ }^{13}$ Originally, we had a fourth category for immigrants' ties to terrorism. However, because of the low incidence of this claim (two cases), we combined this category into the broader category of Immigrant Criminality. 
JOBNAME: No Job Name PAGE: 19 SESS: 11 OUTPUT: Tue Sep 17 19:18:15 2013

/Xpp84/wiley_journal/TSQ/tsq_v55_i1/03tsq_12039

${ }^{14}$ Martinez's trial continues to be delayed because of questions raised by the defense regarding his competency to stand trial.

${ }^{15} \mathrm{All} 29 \mathrm{balanced} / \mathrm{mixed}$ cases in this category were Gazette generated.

${ }^{16}$ Virginia HB 2622 (2007).

${ }^{17}$ In fact, in the few cases where a link was found with the category of culture, it was rarely to connect immigrant criminality to culture directly but instead to use them as distinct arguments. For instance, in a letter to the editor, we find the author stating that America is not against immigrants but is against "1. People who come here illegally, and 2. People who will not learn and use our common language" (Walsh, Letters to the Editor, August 12, 2006).

${ }^{18}$ Based on data from the 2005 Citizenship, Involvement and Democracy Survey (CIDS) and the 2006 Cooperative Congressional Election Study (CCES), Sides and Citrin (2007:9-10) find that Americans on average overestimate the foreign-born population by a factor of two, and the number of "illegal" immigrants by a factor of six or seven.

${ }^{19}$ In 2007, in Prince William County, VA, the county board of supervisors passed an ordinance requiring police to check the status of anyone suspected of being an undocumented worker. This was later revised to only allow for immigration status checks for those already under arrest (Wolgin and Kelley 2011).

${ }^{20}$ The exchange between Corey Stewart, Chairman of the Prince William Board of County Supervisor, and Linda Chavez, Virginia Advisory Committee Chair, US Commission on Civil Rights is captured in the documentary 9500 Liberty (Park and Byler 2009).

${ }^{21}$ Arizona's SB 1070, passed in 2010, and Alabama's HB 56, passed in 2011, requires police to determine an individual's immigration status during a lawful stop, detention or arrest if there is "reasonable suspicion" that the individual is an undocumented immigrant (Arizona State Senate Bill 1070 • (Support Our Law Enforcement and Safe Neighborhood Act); Alabama House Bill 56 • (Hammon-Beason Alabama Taxpayer and Citizen Protection Act)).

\section{REFERENCES}

Alabama House Bill 56. $\cdot$. Hammon-Beason Alabama Taxpayer and Citizen Protection Act. Retrieved April 19, 2012. (http://alisondb.legislature.state.al.us/acas/searchableinstruments/ 2011rs/bills/hb56.htm).

Arizona State Senate Bill 1070. $\cdots$. Support Our Law Enforcement and Safe Neighborhood Act. Retrieved April 19, 2012. (http://www.azleg.gov/legtext/49leg/2r/bills/sb1070s.pdf).

Benford, Robert D. and David A. Snow. 2000. "Framing Processes and Social Movements: An Overview and Assessment." Annual Review of Sociology 26:611-39.

Blalock, Hubert M. 1967. Toward A Theory of Minority-group Relations. New York: Capricorn Books.

Blumer, Herbert. 1958. "Race Prejudice As A Sense of Group Position." Pacific Sociological Review $1: 3-7$.

Brettell, Caroline B. and Faith G. Nibbs. 2010. "Immigrant Suburban Settlement and the 'Threat' to Middle Class Status and Identity: The Case of Farmers Branch, Texas." International Migration 49:1-30.

Brewer, Janice K. 2010. Statement by Governor Jan Brewer. ․: Press Release. Retrieved February 11, 2013. (http://azgovernor.gov/dms/upload/PR_042310_StatementByGovernorOnSB1070 .pdf).

Butcher, Kristin F. and Anne Morrison Piehl. 1998. "Cross-city Evidence on the Relationship between Immigration and Crime." Journal of Policy Analysis and Management 17:457-93. 
JOBNAME: No Job Name PAGE: 20 SESS: 11 OUTPUT: Tue Sep 17 19:18:15 2013

/Xpp84/wiley_journal/TSQ/tsq_v55_i1/03tsq_12039

Perceptions of Immigrant Criminality

Deenesh Sohoni and Tracy W. P. Sohoni

Chavez, Leo. 2001. Covering Immigration: Popular Images and the Politics of the Nation. Berkeley: University of California Press.

—. 2008. The Latino Threat: Constructing Immigrants, Citizens, and the Nation. Stanford: Stanford University Press.

Citrin, Jack and John Sides. 2008. "Immigration and the Imagined Community in Europe and the United States." Political Studies 56:33-56.

Clapp, Susan. 2011. Hispanics in Virginia. *: Weldon Cooper Center for Public Service. University of Virginia. Retrieved May 22, 2012. (http://www.coopercenter.org/demographics/ publications/hispanics-virginia).

Cohen, Tom and Bill Mears. "Supreme Court Mostly Rejects Arizona Immigration Law; Gov Says 'Heart' Remains.” CNN. 6/25/2012. Retrieved June 26, 2012. (http://articles.cnn.com/201206-25/politics/politics_scotus-arizona-law_1_arizona-immigration-law-immigration-statusarizona-association?_s=PM:POLITICS).

Colonial Williamsburg Foundation. 2010. President's Report. Retrieved February 3, 2012. (http:// www.history.org/Foundation/Annualrpt10/index.cfm).

Dawkins, Casey J. C., Theodore Koebel, Marilyn S. Cavell, and Patricia L. Renneckar. 2007. Housing Needs Assessment: James City County and Williamsburg. •.: Virginia Center for Housing Research Virginia Tech. Retrieved January 6, 2008. (http://www.jccegov.com/pdf/ bospdfs/bospdfs2007/121107readfile/item3.pdf).

de Vreese, Claes H. 2012. "New Avenues for Framing Research.” American Behavioral Scientist 56:365-75.

Desmond, Scott. A. and Charis. E. Kubrin. 2009. “The Power of Place: Immigrant Communities and Adolescent Violence." The Sociological Quarterly 50:581-607.

Dick, Hilary P. 2011. "Making Immigrants Illegal in Small-town USA." Journal of Linguistic Anthropology 21(Suppl. 1):E35-E55.

Escobar v. Brewer et al. 2010. 4:10-cv-00249-DCB. District Court for the State of Arizona. Retrieved May 1, 2012. (http://images.bimedia.net/documents/Officer_Complaint_SB10 .pdf).

Federal Bureau of Investigation. 2012. Uniform Crime Reports for the United States. Washington, DC: U.S. Government Printing Office. Retrieved on May 1, 2012. (http://www.bjs.gov/ ucrdata/Search/Crime/Crime.cfm).

Gamson, William A., David Croteau, William Hoynes, and Theodore Sasson. 1992. "Media Images and the Social Construction of Reality." Annual Review of Sociology 18:373-93.

Gamson, William A. and Andre Modigliani. 1989. "Media Discourse and Public Opinion on Nuclear Power: A Constructionist Approach.” American Journal of Sociology 95:1-37.

Gilliam, Franklin D. Jr and Shanto Iyengar. 2000. "Prime Suspects: The Influence of Local Television News on the Viewing Public." American Journal of Political Science 44:560-73.

Gonzalez, Juan and Amy Goodman (Interviewers) and Lou Dobbs (Interviewee). 2007. "Fact-Checking Dobbs: CNN Anchor Lou Dobbs Challenged on Immigration Issues." Democracynow.org. Dec 4, 2007. Interview Transcript. Retrieved April 19, 2012. (http://www .democracynow.org/2007/12/4/fact_checking_dobbs_cnn_anchor_lou).

Hagan, John and Alberto Palloni. 1999. "Sociological Criminology and the Mythology of Hispanic Immigration and Crime." Social Problems 46:617-32.

Haney López, Ian F. 1996. White By Law. New York: New York Univ. Press.

Higham, John. 1955. Strangers in the Land: Patterns of American Nativism 1860-1925. New Brunswich: Rutgers University Press. 
JOBNAME: No Job Name PAGE: 21 SESS: 11 OUTPUT: Tue Sep 17 19:18:15 2013

/Xpp84/wiley_journal/TSQ/tsq_v55_i1/03tsq_12039

Honig, Bonnie. 2001. Democracy and the Foreigner. Princeton, NJ: Princeton University Press.

Jones, Richard C., ed. 2008. Immigrants Outside Megalopolis: Ethnic Transformation In The Heartland. Lantham, MD: Lexington Books.

Kohut, Andrew, Scott Ketter, Carroll Doherty, Roberto Suro, and Gabriel Escobar. 2006. America's Immigration Quandary. Report prepared by the Pew Research Center for the People \& the Press and the Pew Hispanic Center. Retrieved January 5, 2010. (http://people-press.org/ reports/pdf/274.pdf).

Lamont, Michèle and Virág Molnár. 2002. "The Study of Boundaries in the Social Sciences." Annual Review of Sociology 28:167-95.

Lee, Matthew T., Ramiro Martinez Jr, and Richard Rosenfeld. 2001. "Does Immigration Increase Homicide? Negative Evidence from Three Border Cities." The Sociological Quarterly 42:559-80.

Lopez, Kristina M. and Holly V. Miller. 2011. "Ethnicity, Acculturation, and Offending: Findings from A Sample of Hispanic Adolescents." The Open Family Studies Journal 4:27-37.

Martinez, Ramiro and Matthew T. Lee. 2000. "On Immigration and Crime." Pp. •_•• in Criminal Justice 2000: The Changing Nature of Crime, Vol. I, edited by Gary LaFree and Robert J. Bursik Jr. Washington, DC: National Institute of Justice.

Martinez, Ramiro Jr. 2002. Latino Homicide: Immigration, Violence and Community. New York: Routledge Press.

Massey, Douglas, ed. 2008. New Faces in New Places: The Changing Geography of American Immigration. New York: Russell Sage Foundation.

Miller, Holly, V. 2012. "Correlates of Delinquency and Victimization in A Sample of Hispanic Youth." International Criminal Justice Review 22:153-70.

Mohl, Raymond. 2003. "Globalization, Latinization, and the Nuevo New South." Journal of American Ethnic History 22:31-66.

Morenoff, Jeffrey. D. and Avraham Astor. 2006. "Immigrant Assimilation and Crime: Generational Differences in Youth Violence in Chicago." Pp. ...• in Immigration and Crime: Race, Ethnicity, and Violence, edited by Ramiro Martinez and Abel Valenzuela, New York: New York University Press.

Ousey, Graham C. and Charis E. Kubrin. 2009. "Exploring the Connection between Immigration and Violent Crime Rates in U.S. Cities, 1980-2000." Social Problems 56:447-73.

Ousey, Graham C. and James D. Unnever. 2012. "Racial-Ethnic Threat, Out-group Intolerance, and Support for Punishing Criminals: A Cross-national Study." Criminology 50:565-603.

Park, Annabel and Eric Byler. 2009. Taxpayer \$ Funded "Field Study" for SB 1070 Authors in Virginia. Scene from 9500 Liberty. Retrieved June 19, 2012. (http://www.youtube.com/ watch?v=YeoTsapAmK4\&feature=player_embedded).

Perea, Juan F., ed. 1997. Immigrants Out! The New Nativism and the Anti-Immigrant Impulse in the United States. New York: New York University Press.

Pew Hispanic Center. 2009. Where Latino/as Live. Retrieved January 6, 2009. (http://pewhispanic .org/reports/report.php?ReportID=96/).

PollingReport.com. 2010. Retrieved January 6, 2010. (http://www.pollingreport.com/ immigration2.htm).

Salgado v. Brewer et al. 2010. 2:10-cv-00951-ROS. District Court for the State of Arizona. Retrieved May 1, 2012. (http://www.azcentral.com/ic/pdf/0429immigration-lawsuit-salgado .pdf).

Sampson, Robert. 2008. "Rethinking Crime and Immigration." Contexts 7:28-33. 
JOBNAME: No Job Name PAGE: 22 SESS: 11 OUTPUT: Tue Sep 17 19:18:15 2013

/Xpp84/wiley_journal/TSQ/tsq_v55_i1/03tsq_12039

Perceptions of Immigrant Criminality

Deenesh Sohoni and Tracy W. P. Sohoni

Santa Ana, Otto. 2002. Brown Tide Rising: Metaphors of Latinos in Contemporary American Discourse. Austin, TX: University of Texas Press.

Sides, John and Jack Citrin. 2007. How Large the Huddled Masses? The Causes and Consequences of Public Misperceptions about Immigrant Populations. Paper presented at the 2007 Annual Meeting of the Midwest Political Science Association.

Sohoni, Deenesh and Jennifer Bickham Mendez. 2012. "Defining Immigrant Newcomers in New Destinations: Symbolic Boundaries in Williamsburg, VA.” Ethnic and Racial Studies •..•-_ ••. DOI:10.1080/01419870.2012.716521.

Sohoni, Deenesh. 2006. “The Immigrant Problem: Modern Day Nativism on the Web." Current Sociology 54:827-50.

Stowell, Jacob I., Steven F. Messner, Kelly F. McGeever, and Lawrence E. Raffalovich. 2009. "Immigration and the Recent Violent Drop in the United States: A Pooled, Cross-sectional Time-Series Analysis of Metropolitan Areas." Criminology 47:889-928.

Sutherland, Edwin H. 1927. Is There Undue Crime among Immigrants? Official Proceedings of the Annual Meeting of the National Conference on Social Welfare.

—. 1934. Criminology. Philadelphia, PA: J. B. Lippincott Co.

US Census Bureau. 2009. Table 1: Annual Estimates of the Population for Counties of Virginia: April 1, 2000 to July 1, 2007. US Census Bureau.

Virginia Gazette. 2012. About Us. Retrieved August 10, 2012. (http://www.vagazette.com/ services/va-services_gazhistory,0,5332906.story?page=1).

Wadsworth, Tim. 2010. "Is Immigration Responsible for the Crime Drop? An Assessment of the Influence of Immigration on Changes in Violent Crime Between 1990 and 2000." Social Science Quarterly 91:531-53.

Weldon Cooper Center for Public Service. 2011. Data published on February 14, 2011 by the Demographics \& Workforce Group- Population Data. Retrieved April 19, 2012. (http:// www.coopercenter.org/demographics).

Wolgin, Philip E. and Angela M. Kelley. 2011. Your State Can't Afford It: The Fiscal Impact of States' Anti-Immigration Legislation. •.: Center for American Progress. Retrieved April 19, 2012. (http://www.americanprogress.org/issues/2011/07/state_immigration.html).

Zolberg, Aristide. 2000. "Matters of the State: Theorizing Immigration Policy.” Pp. •... in The Handbook of International Migration, edited by Charles Hirschman, Philip Kasinitz, and Josh De Wind, New York: Russell Sage Foundation.

\section{APPENDIX 1: VIRGINIA GAZETTE CITATIONS}

Beachum, Ken. 2007. “Uphold the Constitution.” Virginia Gazette—Essay. (9/29/2007). Burke, Bill. 2006. "Exploiters.” Virginia Gazette- Letters (6/14/2006).

Byrd, Mitchell. A. 2007. "We are now less secure." Virginia Gazette-Letters (7/25/2007).

Danko, Judy. 2007. “Accept Illegals.” Virginia Gazette—Letters (8/25/2007).

Dowling, Bill. 2007. "Illegal Sanctuary?” Virginia Gazette— Letters (8/29/2007).

Johnson, Cecil. 2006. “Equal Rights for Citizens.” Virginia Gazette—Staff Columnist: Curmudgeon. (5/10/2006).

Johnson, Cecil. 2007. “Close our Open Borders.” Virginia Gazette—Staff Columnist: Curmudgeon. (9/19/2007).

Kerr, Amanda. 2006. "Immigrants Flock to Fill Good Jobs." Virginia Gazette—Staff Columnist: La Vida Latina. (5/5/2006). 
JOBNAME: No Job Name PAGE: 23 SESS: 11 OUTPUT: Tue Sep 17 19:18:15 2013

/Xpp84/wiley_journal/TSQ/tsq_v55_i1/03tsq_12039

Kerr, Amanda. 2007. “Illegal Immigrants Charged in Attack.” Virginia Gazette.

$(5 / 2 / 2007)$.

Koenig, David. W. 2007. “Tracking Immigrants.” Virginia Gazette—Letters (2/7/2007). Leadbeater, Lew. 2007. "Beware Academic Bill." Virginia Gazette- Staff Columnist:

Notes from the Edge (1/24/2007).

Police Blotter. 2006. Virginia Gazette (12/23/06).

Scorecard. 2007. Virginia Gazette (11/10/07).

Shepherd, F.S. 2006. "Embrace Legal Immigrants.” Virginia Gazette- Letters (1/11/06).

Walsh, James. M. 2006. “Use English.” Virginia Gazette- Letters (8/12/2006).

Wittman, Rob. 2007. Campaign Advertisement. Virginia Gazette (12/8/2007). 


\section{AUTHOR QUERY FORM}

Dear Author,

During the preparation of your manuscript for publication, the questions listed below have arisen. Please attend to these matters and return this form with your proof.

Many thanks for your assistance.

\begin{tabular}{|c|c|c|}
\hline $\begin{array}{l}\text { Query } \\
\text { References }\end{array}$ & Query & Remarks \\
\hline 1 & $\begin{array}{l}\text { AUTHOR: Citations "Last Word 5/13/06" have been changed to } \\
\text { "Last Word, Virginia Gazette, May 15, 2006." Please check that this is } \\
\text { correct. }\end{array}$ & \\
\hline 2 & AUTHOR: Please provide the full form of DUI. & \\
\hline 3 & $\begin{array}{l}\text { AUTHOR: "More ... US." This sentence has been reworded for } \\
\text { clarity. Please check that this is correct. }\end{array}$ & \\
\hline 4 & $\begin{array}{l}\text { AUTHOR: Please supply the years of publications for the References } \\
\text { in the Reference List. }\end{array}$ & \\
\hline 5 & $\begin{array}{l}\text { AUTHOR: Please check all website addresses and confirm that they } \\
\text { are correct. (Please note that it is the responsibility of the author(s) } \\
\text { to ensure that all URLs given in this article are correct and useable.) }\end{array}$ & \\
\hline 6 & $\begin{array}{l}\text { AUTHOR: Please supply the city locations of the publishers for the } \\
\text { References in the Reference List. }\end{array}$ & \\
\hline 7 & $\begin{array}{l}\text { AUTHOR: Please list all the defendants if necessary for the Refer- } \\
\text { ences in the References in the Reference List. }\end{array}$ & \\
\hline 8 & $\begin{array}{l}\text { AUTHOR: Please supply page ranges for the References in the Refer- } \\
\text { ence List. }\end{array}$ & \\
\hline 9 & $\begin{array}{l}\text { AUTHOR: Please confirm that the year of publication is correct for } \\
\text { Reference PollingReport.com, } 2010 \text {. }\end{array}$ & \\
\hline 10 & $\begin{array}{l}\text { AUTHOR: Please supply the volume number and page range for } \\
\text { Reference Sohoni, Mendez } 2012 .\end{array}$ & \\
\hline
\end{tabular}

